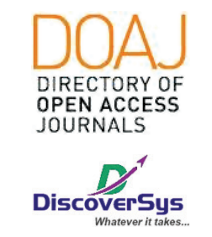

Published by DiscoverSys

\section{Perilaku hand hygiene tenaga kesehatan di RSUP Sanglah tahun 2018}

\author{
Made Dwi Andhika Yogiswara, ${ }^{1 *}$ Ni Luh Putu Ariastuti, ${ }^{2}$ Putu Aryani ${ }^{2}$
}

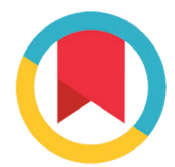

CrossMark

\title{
ABSTRACT
}

Background: Low hand hygiene behavior is a very detrimental and a cause of health care associated infection and is a problem faced by patients and the medical profession at this time. The purpose of this study was to find out the distribution of hand hygiene behavior among healthcare professionals in Sanglah General Hospital Denpasar.

Method: This study was conducted using a descriptive method with a cross-sectional study design carried out in the polyclinic and inpatients ward at Sanglah General Hospital in September to November 2018.
Results: From the 96 study samples, $82.3 \%$ had good compliance with hand hygiene standards and $68.7 \%$ had a positive perception of hand hygiene. Women are more obedient than men towards the implementation of hand hygiene and doctors is the lowest profession to have a level of adherence to hand hygiene.

Conclusion: Perception and compliance with hand hygiene in medical personnel at Sanglah General Hospital Denpasar has been very good, but it still needs to be improved so that all medical personnel perform hand hygiene procedures as a routine practice for the sake of infection prevention and control.

Keywords: hand washing, infection, behavior, attitude.

Cite This Article: Yogiswara, M.D.A., Ariastuti, N.L.P., Aryani, P. 2019. Perilaku hand hygiene tenaga kesehatan di RSUP Sanglah tahun 2018. Intisari Sains Medis 10(3): 501-505. D0l: 10.15562/ism.v10i3.430

\section{ABSTRACT}

Latar Belakang: Prilaku hand hygiene yang rendah merupakan suatu hal yang amat merugikan dan menjadi penyebab dari health care associated infection dan menjadi masalah yang dihadapi untuk pasien dan juga profesi medis saat ini. Tujuan dari penelitian ini yaitu untuk mengetahui distribusi perilaku hand hygiene di kalangan profesi-profesi tenaga kesehatan di RSUP Sanglah Denpasar.

Metode: Penelitian ini dilakukan dengan menggunakan metode deskriptif dengan desain penelitian potong lintang (cross sectional) yang dilaksanakan di poliklinik dan ruang rawat RSUP Sanglah pada bulan September sampai November 2018.
Hasil: Dari keseluruhan 96 sampel penelitian, 82,3\% memiliki kepatuhan terhadap standar hand hygiene dan 68,7\% memiliki persepsi yang positif terhadap hand hygiene. Perempuan cenerung lebih patuh dibandingkan dengan laki-laki terhadap pelaksanaan hand hygiene dan dokter mudah merupakan profesi yang paling rendah memiliki tingkat kepatuhan terhadap hand hygiene.

Simpulan: Persepsi dan kepatuhan akan hand hygiene pada tenaga medis di RSUP Sanglah Denpasar sudah sangat baik, akan tetapi hal tersebut masih perlu ditingkatkan sehingga seluruh kalangan tenaga medis melakukan prosedur hand hygiene sebagai suatu kebiasaan rutin untuk untuk kepentingan melakukan pencegahan dan pengendalian infeksi.
${ }^{1}$ Program Studi Pendidikan Dokter, Fakultas Kedokteran Universitas Udayana

2Departemen Kedokteran Masyarakat dan Kedokteran Pencegahan, Fakultas Kedokteran, Universitas Udayana

*Corresponding email: Made Dwi Andhika Yogiswara, Program Studi Pendidikan Dokter, Fakultas Kedokteran Universitas Udayana madeyogiswagra@gmail.com

Diterima: 06-03-2019

Disetujui: 06-04-2019

Diterbitkan: 01-12-2019
Kata kunci: cuci tangan, infeksi, prilaku, sikap.

Cite Pasal Ini: Yogiswara, M.D.A., Ariastuti, N.L.P., Aryani, P. 2019. Perilaku hand hygiene tenaga kesehatan di RSUP Sanglah tahun 2018. Intisari Sains Medis 10(3): 501-505. D0l: 10.15562/ism.v10i3.430

\section{PENDAHULUAN}

Health Care-Associated Infection (HCAI) masih menjadi permasalahan bagi pelayanan medis dunia. Data dari Center for Disease Control and Prevention (CDC) menyatakan bahwa sebanyak 722.000 kasus HCAI dilaporkan di Amerika Serikat, 75.000 pasien diantaranya meninggal. HCAI juga mengancam 5-15\% pasien rawat inap dan 9-37\% pasien Intensive Care Unit di Amerika Serikat. ${ }^{1}$ Laporan Tahunan RSUP Sanglah menyatakan angka kejadian Hospital-acquired Infection (HAI) 0-9\% dengan angka kejadian infeksi pasca operasi dibawah 1,5\% pada tahun 2015 .

Kementerian Kesehatan menekankan perilaku hand hygiene sebagai salah satu pengendali HCAI. Tenaga kesehatan memiliki kemungkinan kontak dengan pasien dan lingkungan pasien yang membawa mikroorganisme dominan di instansi rumah sakit seperti Methicillin-Resistant 
Staphylococcus aureus, Vancomycin-Resistant Enterococci, Escherichia coli, Morganella sp., dan sebagainya. ${ }^{2,3}$ Hal ini menandakan pentingnya upaya preventif seperti hand hygiene sebagai pencegah dan pengendali infeksi sangat diperlukan dengan menghambat pertumbuhan patogen yang bersumber dari tenaga kesehatan dengan standar yang mampu melindungi pasien dan tenaga kesehatan itu sendiri dari infeksi. ${ }^{4}$

Sebuah penelitian di sebuah rumah sakit di Malang menemukan bahwa perilaku hand hygiene pada tenaga kesehatan di instalasi rawat inap masih sangat rendah, yaitu 35\% dimana angka pelaksanaan tertinggi ditemukan pada saat sesudah kontak atau melakukan tindakan pada pasien, sedangkan perilaku hand hygiene sebelum kontak sangat rendah bahkan nol pada saat sebelum kontak dengan pasien. ${ }^{5}$ Tren serupa juga didapat di studi yang dilakukan di RSUP Sanglah dimana perilaku hand hygiene dokter paling rendah terjadi sebelum melakukan tindakan aseptik sebesar $45,1 \%$ pada kasus kejadian VAP. ${ }^{6}$ Pada studi lain dikemukakan bahwa tenaga kesehatan dengan tingkat kontak dengan pasien yang lebih tinggi seperti perawat cenderung melakukan hand hygiene lebih sering. Scheithauer dalam studinya mendapatkan perawat memiliki angka hand hygiene yang lebih tinggi dibandingkan dengan dokter baik di ruang perawatan pediatri maupun neonatal. ${ }^{7}$ Selain itu, motivasi dalam melakukan hand hygiene juga mengambil andil. Tenaga kesehatan muda di instansi kesehatan cenderung menjadikan atasannya sebagai role model dalam perilaku hand hygiene. ${ }^{8}$

Untuk RSUP Sanglah sendiri, belum ada data mengenai perilaku hand hygiene lintas profesi. Oleh karena itu, tujuan dilakukannya studi dalam distribusi perilaku hand hygiene di kalangan profesi-profesi tenaga kesehatan dan interpretasinya sehingga dapat dijadikan evaluasi dan acuan dalam menargetkan program peningkatan perilaku hand hygiene dan mengurangi angka kejadian HCAI.

\section{METODE}

Penelitian ini dilakukan dengan menggunakan metode deskriptif dengan desain penelitian potong lintang (cross sectional) yang dimaksudkan untuk mendeskripsikan data yang diambil hanya satu kali dan hasil yang diperoleh selanjutnya digambarkan berdasarkan tujuan penelitian yang akan dicapai. Penelitian dilaksanakan di poliklinik dan ruang rawat RSUP Sanglah pada bulan September sampai November 2018. Populasi target dalam penelitian ini adalah seluruh tenaga kesehatan yang bekerja di lingkungan RSUP Sanglah (dokter spesialis, dokter residen, dokter muda, perawat, dan paramedic).
Kriteria inklusi dari penelitian ini adalah bersedia menjadi sampel dan mengisi lembar inform consent. Teknik pengumpulan sampel yang digunakan dalam penelitian ini adalah cluster random sampling. Dilakukan penelusuran pada karakteristik subyek seperti usia, profesi tenaga kesehatan, jenis kelamin, dan tingkat pendidikan. Kemudian dilakukan penelusuran terhadap prilaku dan persepsi hand hygiene dan fasilitas hand hygiene. Analisis dilakukan dengan menggunakan bantuan perangkat lunak SPSS versi 25.0, data dilakukan analisis secara deskriptif dan ditampilkan dalam bentuk tabel.

\section{HASIL}

Dari 100 kuesioner yang dibagikan di 5 poliklinik yang terpilih sebagai cluster sample (Hemodialisis, Rehabilitasi Medik, Poliklinik THT-KL, Poliklinik Mata, dan Poliklinik Penyakit Dalam) didapatkan 96 responden yang termasuk dalam kriteria inklusi. Karakteristik responden penelitian dapat dilihat pada tabel 1.

Sebagian besar responden memiliki jenis kelamin perempuan $(65,6 \%)$. Hampir setengahnya adalah perawat $(46,9 \%)$. Hal ini sejalan dengan laporan tahunan RSUP Sanglah Denpasar tahun 2016 dimana tenaga keperawatan mendominasi jenis profesi yang ada di RSUP Sanglah sebanyak 40,16\% dan disusul dengan tenaga medis seperti dokter spesialis, dokter umum, dokter gigi, dan dokter BSB. Dapat diketahui juga bahwa mayoritas responden telah menempuh jenjang profesi sarjana $(44,8 \%)$. Hanya sebagian kecil dari responden yang menempuh jenjang magister (2\%). Berdasarkan kepatuhan hand hygiene lebih banyak responden yang patuh dibandingkan dengan tidak patuh $(82,3 \%)$. Berdasarkan persepsi hand hygiene terdapat mayoritas dari responden memiliki persepsi yang positif (68,7\%) (Tabel 2).

Pada tabel 2 dapat diketahui bahwa pada lakilaki tingkat kepatuhan dalam perilaku hand hygiene lebih rendah bila dibandingkan dengan perempuan $(69,7 \%$ dan $88,9 \%)$. Tingkat kepatuhan hand hygiene pada perawat sebesar $86,7 \%$. Responden yang telah menempuh jenjang diploma memiliki kepatuhan melakukan hand hygiene yang lebih tinggi dibandingkan dengan responden yang telah menempuh jenjang sarjana (Tabel 2).

Pada tabel 3, Penelusuran mengenai ketersediaan fasilitas hand hygiene ditemukan tempat tisu terdapat di $80 \%$ poliklinik, tetapi tisu hanya tersedia di $60 \%$ poliklinik. Pada observasi, terdapat poliklinik yang tidak menempatkan tisu pada tempat tisu seperti di ruang hemodialisis. Hal ini disebabkan oleh pengunaan fasilitias cuci tangan yang sering. Pengelola 
Tabel 1 Distribusi Frekuensi Karakteristik Responden

\begin{tabular}{|c|c|c|}
\hline Karakteristik Responden & Jumlah & $(\%)$ \\
\hline \multicolumn{3}{|l|}{ Jenis Kelamin } \\
\hline Laki-laki & 33 & 34,4 \\
\hline Perempuan & 63 & 65,6 \\
\hline \multicolumn{3}{|l|}{ Profesi } \\
\hline Dokter umum (Residen) & 37 & 38,5 \\
\hline Perawat & 45 & 46,9 \\
\hline Dokter muda & 12 & 12,5 \\
\hline Psikolog & 2 & 2,1 \\
\hline \multicolumn{3}{|l|}{ Pendidikan Terakhir } \\
\hline Jenjang magister & 2 & 2,1 \\
\hline Jenjang profesi sarjana & 43 & 44,8 \\
\hline Jenjang sarjana & 18 & 18,8 \\
\hline Jenjang diploma & 33 & 34,4 \\
\hline \multicolumn{3}{|l|}{ Prilaku Hand Hygiene } \\
\hline Patuh & 79 & $82,3 \%$ \\
\hline Tidak patuh & 17 & $17,7 \%$ \\
\hline \multicolumn{3}{|l|}{ Persepsi Hand Hygiene } \\
\hline Positif & 66 & $68,7 \%$ \\
\hline Netral & 16 & $16,6 \%$ \\
\hline Negatif & 14 & $14,7 \%$ \\
\hline Jumlah & 96 & 100,0 \\
\hline
\end{tabular}

Tabel 2 Distribusi Frekuensi Perilaku Hand Hygiene Berdasarkan Predisposing Factor

\begin{tabular}{lccc}
\hline & \multicolumn{2}{c}{ Perilaku Hand Hygiene } & \\
\cline { 2 - 3 } Predisposing Factor & Patuh (\%) & Tidak Patuh (\%) & Total (\%) \\
\hline Jenis Kelamin & & & \\
$\quad$ Laki-laki & $23(69,7 \%)$ & $10(30,3 \%)$ & $33(100,0 \%)$ \\
$\quad$ Perempuan & $56(88,9 \%)$ & $7(11,1 \%)$ & $63(100,0 \%)$ \\
Profesi & & & \\
$\quad$ Dokter umum (Residen) & $29(78,4 \%)$ & $8(21,6 \%)$ & $37(100,0 \%)$ \\
$\quad$ Perawat & $39(86,7 \%)$ & $6(13,3 \%)$ & $45(100,0 \%)$ \\
$\quad$ Dokter muda & $9(75,0 \%)$ & $3(25,0 \%)$ & $12(100,0 \%)$ \\
$\quad$ Psikolog & $2(100,0 \%)$ & $0(0,0 \%)$ & $2(100,0 \%)$ \\
Pendidikan Terakhir & & & \\
$\quad$ Jenjang magister & $2(100,0 \%)$ & $0(0,0 \%)$ & $2(100,0 \%)$ \\
$\quad$ Jenjang profesi sarjana & $34(79,1 \%)$ & $9(20,9 \%)$ & $43(100,0 \%)$ \\
$\quad$ Jenjang sarjana & $15(83,3 \%)$ & $3(16,7 \%)$ & $18(100,0 \%)$ \\
$\quad$ Jenjang diploma & $28(84,8 \%)$ & $5(15,2 \%)$ & $33(100,0 \%)$ \\
Total (\%) & $79(82,3 \%)$ & $17(17,7 \%)$ & $96(100,0 \%)$ \\
\hline
\end{tabular}

ruangan tidak memiliki cukup waktu untuk menata kembali tisu baru pada tempat tisu karena pekerjaan yang banyak, sehingga umumnya tisu baru tersebut diletakkan di atas meja jaga.
Dalam observasinya, poliklinik yang tidak menyediakan tisu adalah poliklinik THT-KL dan rehabilitasi medik. Sedangakan poliklinik yang tidak memiliki instruksi mencuci tangan antara lain poliklinik rehabilitas medik dan hemodialisis. Pada tabel 4, diketahui bahwa persentase kepatuhan dalam melaksanakan hand hygiene pada poliklinik yang menyediakan tisu dan instruksi mencuci tangan lebih rendah dibandingkan dengan poliklinik yang tidak menyediakan walaupun angka tersebut tidak berbeda jauh. Hal ini berbeda dari ekspektasi dimana ketersediaan fasilitas tidak semata-mata mendukung pelaksanaan hand hygiene dan meningkatkan kepatuhannya.

\section{PEMBAHASAN}

Perilaku hand hygiene merupakan salah satu prioritas dalam pencegahan infeksi nosokomial. Mikroorganisme yang terdapat pada tangan dapat berkurang sebanyak $36 \%$ apabila dicuci menggunakan air mengalir dan sabun. ${ }^{9}$ Dengan berkurangnya mikroorganisme pada tangan, maka transmisi silang yang terjadi akan lebih sedikit.

Perilaku hand hygiene dilakukan pada 5 momen dengan 6 langkah mencuci tangan sesuai dengan pedoman WHO. Mencuci tangan itu sendiri dapat dilakukan menggunakan alcohol rub maupun air mengalir dan sabun. Pada saat pelaksanaannya, mencuci tangan idealnya dilakukan selama 20-30 detik untuk memaksimalkan potensi agen antiseptik untuk menghilangkan bakteri dan kotoran pada tangan.

Fuentes-Gomez dkk ${ }^{11}$ menyatakan ada berbagai faktor yang mempengaruhi seseorang untuk mencuci tangan, sesuai dengan model precede-proceed yang dikembangkan oleh Green dan Kreuter ${ }^{12}$ dimana faktor-faktor tersebut meliputi predisposing factor, reinforcing factor, dan enabling factor.

Enabling factor terpenting dalam melaksanakan hand hygiene adalah tersedianya fasilitas cuci tangan dengan kondisi yang baik. Tanpa tersedianya fasilitas mencuci tangan, seseorang tidak akan bisa mencuci tangan walaupun sudah terindikasi untuk mencuci tangan. Fasilitas yang tidak adekuat juga menyebabkan pelaksanaan hand hygiene yang tidak ideal dan bahkan mengurangi keinginan seseorang untuk mencuci tangan. ${ }^{11}$

Kondisi wastafel yang mudah diakses seperti dekat dengan point of care serta kondisi wastafe dan drainase yang baik merupakan salah satu poin penting WHO dalam meningkatkan kualitas fasilitas cuci tangan di rumah sakit. ${ }^{10}$ Berdasarkan tabel 3, seluruh poliklinik tempat responden bekerja memiliki wastafel dengan akses, kondisi, dan drainase yang baik. Hal ini sesuai dengan temuan Devnani $\mathrm{dkk}^{13}$ pada survey fasilitas mencuci tangan di rumah 
Tabel 3 Hasil Observasi Fasilitas Pendukung Hand Hygiene

\begin{tabular}{|c|c|c|}
\hline Checklist & & Poliklinik (\%) \\
\hline \multirow[t]{2}{*}{ Wastafel } & Ada & $5(100,0 \%)$ \\
\hline & Tidak ada & $0(0,0 \%)$ \\
\hline \multirow[t]{2}{*}{ Akses wastafel } & Dapat diakses & $5(100,0 \%)$ \\
\hline & Tidak dapat diakses/rusak & $0(0,0 \%)$ \\
\hline \multirow[t]{2}{*}{ Kondisi fisik wastafel } & Bekerja dengan baik & $5(100,0 \%)$ \\
\hline & Rusak & $0(0,0 \%)$ \\
\hline \multirow[t]{2}{*}{ Tipe keran } & Hand operated & $5(100,0 \%)$ \\
\hline & Elbow operated & $0(0,0 \%)$ \\
\hline \multirow[t]{2}{*}{ Kondisi keran } & Bekerja dengan baik & $5(100,0 \%)$ \\
\hline & Rusak & $0(0,0 \%)$ \\
\hline \multirow[t]{3}{*}{ Ketersediaan tempat sabun } & Ada & $5(100,0 \%)$ \\
\hline & Tidak ada & $0(0,0 \%)$ \\
\hline & Rusak & $0(0,0 \%)$ \\
\hline \multirow[t]{2}{*}{ Ketersediaan antiseptik } & Ada & $5(100,0 \%)$ \\
\hline & Tidak ada & $0(0,0 \%)$ \\
\hline \multirow[t]{3}{*}{ Tipe antiseptik } & Sabun batang & $0(0,0 \%)$ \\
\hline & Sabun cair & $4(80,0 \%)$ \\
\hline & Alcohol rub & $5(100,0 \%)$ \\
\hline \multirow[t]{3}{*}{ Ketersediaan tempat tisu } & Ada & $4(80,0 \%)$ \\
\hline & Tidak ada & $1(20,0 \%)$ \\
\hline & Rusak & $0(0,0 \%)$ \\
\hline \multirow[t]{2}{*}{ Ketersediaan tisu } & Ada & $3(60,0 \%)$ \\
\hline & Tidak ada & $2(40,0 \%)$ \\
\hline \multirow[t]{2}{*}{ Kondisi drainase wastafel } & Lancar & $5(100,0 \%)$ \\
\hline & Terhambat & $0(0,0 \%)$ \\
\hline \multirow{2}{*}{$\begin{array}{l}\text { Ketersediaan instruksi } \\
\text { mencuci tangan }\end{array}$} & Ada & $3(60,0 \%)$ \\
\hline & Tidak ada & $2(40,0 \%)$ \\
\hline
\end{tabular}

Tabel 4 Distribusi Frekuensi Perilaku Hand Hygiene Berdasarkan Ketersediaan Tisu dan Instruksi Mencuci Tangan Perilaku Hand Hygiene

\begin{tabular}{lccc}
\hline & \multicolumn{2}{c}{ Perilaku Hand Hygiene } & \\
\cline { 2 - 3 } Ketersediaan Fasilitas & Patuh (\%) & Tidak Patuh (\%) & Total (\%) \\
\hline Ketersediaan tisu & & & \\
$\quad$ Tersedia & $47(81,0 \%)$ & $11(19,0 \%)$ & $58(100 \%)$ \\
$\quad$ Tidak tersedia & $32(84,2 \%)$ & $6(15,8 \%)$ & $38(100 \%)$ \\
Ketersediaan instruksi & & & \\
mencuci tangan & & & \\
$\quad$ Tersedia & $45(80,3 \%)$ & $11(19,6 \%)$ & $56(100 \%)$ \\
$\quad$ Tidak tersedia & $34(85,0 \%)$ & $6(16,0 \%)$ & $40(100 \%)$ \\
Total (\%) & $79(82,3 \%)$ & $17(17,7 \%)$ & $96(100,0 \%)$ \\
\hline
\end{tabular}

sakit tersier di negara berkembang dimana mayoritas rumah sakit tersier di India memiliki wastafel dengan akses, kondisi, dan drainase yang baik.
Meisa $\mathrm{dkk}^{14}$ mengemukakan bahwa perempuan memiliki peluang 1,5 kali lebih besar untuk berperilaku hand hygiene yang buruk dibandingkan laki-laki. Akan tetapi, pada penelitian tersebut perbandingan antara laki-laki dan perempuan terlampau jauh, yaitu $10: 113$. Di sisi lain, Cahyani ${ }^{15}$ pada penelitian dengan perbandingan antara laki-laki dan perempuan yang hampir sama dengan penelitian ini $(38: 58)$ menegaskan bahwa perempuan memiliki kepatuhan yang lebih baik dibandingkan dengan laki-laki.

Perbedaan temuan dengan penelitian lain dapat disebabkan adanya faktor yang membedakan antara laki-laki dan perempuan dalam mencuci tangan, salah satunya adalah kebisaan mengenai pola hidup bersih. Health Action Model menegaskan adanya perbedaan kebiasaan tersebut antara laki-laki dan perempuan. Hal ini dipengaruhi oleh latar belakang yang berbeda antar jenis kelamin dalam hal edukasi, tumbuh kembang, peran sosial, dan sebagainya. Sehingga, secara tidak langsung akan mempengaruhi bagaimana perilaku cuci tangan dapat berbeda antar jenis kelamin. ${ }^{16}$

Perawat merupakan tenaga kesehatan yang paling sering melakukan kontak fisik dengan pasien. Walaupun seluruh tenaga kesehatan mendapatkan pelatihan dan edukasi yang sama mengenai hand hygiene, indikasi untuk melakukan hand hygiene pada perawat lebih sering terjadi dibandingkan dengan profesi lain. Hal ini menyebabkan perilaku cuci tangan yang lebih sering dilakukan perawat.

Profesi lain seperti dokter umum memiliki kepatuhan yang lebih rendah bila dibandingkan dengan perawat. Padahal, beban dalam melakukan hand hygiene seperti pekerjaan yang menumpuk dan kurangnya waktu yang tersedia lebih sedikit terjadi pada dokter. ${ }^{17}$ Sehingga, ketidak patuhan yang terjadi pada dokter lebih mungkin disebabkan akibat sulitnya menerima perubahan perilaku. ${ }^{18,19}$

Dari data tersebut, dapat diketahui bahwa mayoritas tenaga kesehatan di RSUP Sanglah tahun 2018 sudah patuh dalam berperilaku hand hygiene. Walaupun lebih dari 80\% telah memiliki kepatuhan yang baik, ada sebagian dari tenaga kesehatan yang memiliki persepsi yang negatif terhadap pelaksanaannya. Umumnya, tenaga kesehatan masih merasa kurangnya timbal balik yang diberikan oleh institusi terhadap performa hand hygiene walaupun institusi sudah dirasa mendukung pelaksanaan hand hygiene. Fasilitas hand hygiene sendiri sudah baik, akan tetapi dari beberapa poliklinik yang diobservasi masih ada fasilitas yang belum lengkap, seperti sabun cair, tisu beserta tempatnya, dan instruksi mencuci tangan.

Pada penelitian ini, data mengenai perilaku hand hygiene masih berdasarkan pengakuan dari responden, sehingga memungkinkan adanya bias 
dalam menjawab kuesioner dan menurunkan reliabilitas data. Variabel lain seperti lama bekerja, latar belakang sosioekonomi, dan riwayat penyakit kulit pada penggunaan agen antiseptik juga masih belum diperhitungkan.

\section{SIMPULAN}

Tenaga kesehatan yang patuh dalam berprilaku hand hygiene sebesar 82,3\%. Sebanyak 68,8\% tenaga kesehatan memiliki persepsi yang positif mengenai hand hygiene. Sebanyak 16,7\% tenaga kesehatan memiliki persepsi yang netral. 14,4\% lainnya memiliki persepsi yang negatif. Tingkat kepatuhan tertinggi dalam mencuci tangan terjadi pada responden yang berprofesi sebagai perawat $(86,7 \%)$. Responden yang telah menempuh jenjang magister memiliki kepatuhan dalam perilaku hand hygiene sebesar 100\%, Pada responden yang berpersepsi positif terhadap hand hygiene memiliki tingkat kepatuhan tertinggi (93,3\%). Seluruh poliklinik tempat responden bertugas memiliki wastafel dengan akses, kondisi, dan drainase yang baik, walaupun menggunakan keran bertipe hand operated. Alcohol rub juga tersedia di seluruh poliklinik. Seluruh poliklinik memiliki tempat sabun, namun hanya $80 \%$ yang terisi. Tempat tisu tersedia di $80 \%$ poliklinik, namun hanya $60 \%$ yang terisi. Instruksi mencuci tangan hanya tersedia di $60 \%$ poliklinik.

\section{KONFLIK KEPENTINGAN}

Penulis menyatakan tidak terdapat konflik kepentingan terkait publikasi dari artikel ini.

\section{PENDANAAN}

Penelitian ini tidak mendapatkan hibah dana dari pemerintah ataupun sektor swasta lainnya.

\section{ASPEK ETIKA DALAM PENELITIAN}

Penelitian ini telah mendapatkan persetujuan dari Komite Etik Fakultas Kedokteran/RSUP Sanglah Denpasar dengan nomer referensi 183/ UN14.2.2.VII.14/LP/2018.

\section{DAFTAR PUSTAKA}

1. Klevens R, et al. Estimating Health Care-Associated Infections and Deaths in. Public Health Reports. 2007;122:160-166.

2. Stiefel U, et al. Contamination of Hands with MethicillinResistant Staphylococcus aureus after Contact with Environmental Surfaces and after Contact with the Skin of Colonized Patients. Infect Control Hosp Epidemiol. 2011;32(2):185-187.
3. Derde LPG, et al. Interventions to reduce colonisation and transmission of antimicrobial-resistant bacteria in intensive care units: an interrupted time series study and cluster randomised trial. Lancet Infectious Disease. 2014;14:31-39.

4. Fauzi N, Azzuhri M. Pengaruh Faktor Individu, Organisasi dan Perilaku terhadap Kepatuhan Perawat dalam Melaksanakan Hand Hygiene di Ruang Rawat Inap Rumah Sakit Tk. II Dr. Soepraoen Malang. Jurnal Aplikasi Manajemen. 2015;13(4):566-574.

5. Ernawati E, Wiyanto S. Penerapan Hand Hygiene Perawat di Ruang Rawat Inap Rumah Sakit. Jurnal Kedokteran Brawijaya. 2014;28(1):89-94.

6. Azis A, Parwati T. Laporan hasil penelitian Cuci tangan sebagai faktor risiko kejadian ventilator associated pneumonia di RSUP Sanglah Denpasar tahun 2012. Denpasar. Public Health and Preventive Medicine Archive. 2012;1(2):120-125.

7. Scheithauer S, et al. Hand hygiene in pediatric and neonatal intensive care unit patients: Daily opportunities and indication- and profession-specific analyses of compliance. American Journal of Infection Control. 2011;39(9):732-737.

8. Erasmus V, et al. A Qualitative Exploration of Reasons for Poor Hand Hygiene Among Hospital Workers Lack of Positive Role Models and of Convincing Evidence That Hand Hygiene Prevents Cross-Infection. Infection Control \& Hospital Epidemiology. 2009;30(5):415-419.

9. Burton $\mathrm{M}$, et al. The effect of handwashing with water or soap on bacterial contamination of hands. International Journal of Environmental Research and Public Health. 2011;8(1):97-104.

10. WHO. Hand hygiene: why, how, and when [Internet]. Geneva: WHO Patient Safety; 2009. Tersedia di: https:// www.who.int/gpsc/5may/tools/9789241597906/en/.

11. Fuentes-Gómez V, et al. Predisposing, enabling, and reinforcing factors of hand hygiene in a hospital setting. Revista de Calidad Asistencial. 2012;27(4):197-203.

12. Green L, Kreuter M. Health Program Planning: An Educational and Ecological Approach. 4th edition. New York: McGraw-Hill Higher Education; 2005.

13. Devnani M. et al. A survey of hand-washing facilities in the outpatient department of a tertiary care teaching hospital in India. J Infect Dev Ctries. 2011;5(2):114-118.

14. Meisa A. Gambaran Perilaku Mencuci Tangan Pada Perawat di Rumah Sakit Awal Bros Bekasi Tahun 2012. Jurnal Kesehatan Medika. 2012;1(2):6-20.

15. Cahyani C. Hubungan Jenis Kelamin dengan Tahap Cuci Tangan Mahasiswa Saat Praktikum Di Laboratorium Mikrobiologi Fakiltas Kedokteran Universitas Sebelas Maret Surakarta [Skripsi]. Solo: Universitas Sebelas Maret; 2010.

16. Mazaheri MA, Heidarnia A. The effect of intervention based on health action model to promote workers' safe behavior in Isfahan Steel Company. J Educ Health Promot. 2015;4:64.

17. Azim S, Juergens C, McLaws ML. An average hand hygiene day for nurse and physicians: the burden is not equal. 2016. Am J Infect Control. 2016; 44(7):777-781.

18. Salemi, C., Canola, M.T. \& Eck, E.K., 2014. Hand Washing and Physicians: How to Get Them Together. Infection Control and Hospital Epidemiology, 23(1), pp.32-35.

19. Dahesihdewi A, Dwiprahasto I, Wimbarti S, Mulyono B. Reducing Methicillin-Resistant Staphylococcus Aureus (MRSA) Cross-Infection through Hand Hygiene Improvement in Indonesian Intensive Tertiary Care Hospital. Bali Medical Journal. 2018;7(1):227-233. DOI:10.15562/bmj.v7i1.782.

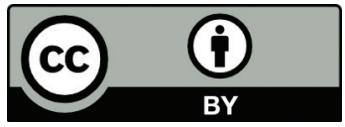

This work is licensed under a Creative Commons Attribution 